\title{
Pastoral care and healing in Africa: Towards an Adamic Christological practical theology imagination for pastoral healing
}

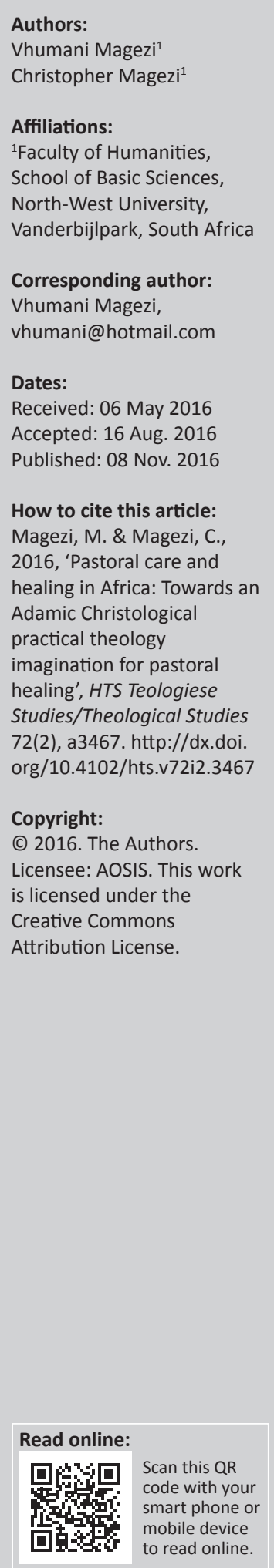

This article argues that the challenge and need for relevant ministry models is critical for effective Christian ministry and pastoral ministry as practical life ministry. It establishes an Adamic Christological model as a paradigm that provides a practical effective ministerial approach in Africa, particularly within the context of pastoral care and healing. This framework reveals Christ's complete identification with African Christians in their contextual sufferings as the New Adam without compromising authentic gospel reality. In employing the Adamic Christological framework as the anchor for African pastoral and healing ministry, a model for African Christians' daily response to their various contextual sufferings is constructed. This responsive model bridges the gap between the ascension of Christ and the interim period of Christianity by instituting God's ongoing personal presence in believers' suffering through the Holy Spirit (pneumatology) as an encouraging and comforting reality that should enable Christians to cope in their suffering. It is argued that this Adamic Christological framework provides a practical theological model that contributes to healing and hope in pastoral care through practical knowing that impacts and imparts meaning in life.

\section{Context framework and study background}

Significant scholarly efforts by African theological scholars such as Bediako (1994), Bujo (1992), Nyamiti (2006), Pobee (1979), Milingo (1984), Kwesi (1984), Mbiti (1989) and many others have underscored the need for a relevant Christian ministry on the continent. This is certainly undisputed. The perceived foreignness of Christ in African Christianity has depicted Christ as unable to effectively respond to the contextual needs of Africans. Banda's (2005:5) observation that resonates with other African theologians is apt in this regard. He rightly stated that 'many Africans perceive Jesus as both a foreign and new idea specifically with his initial emergence and association with White settlers' (2005:5). The newness and foreignness of Christ in African religiosity is connected to 'the fact that Jesus Christ was not part of African religiosity until the arrival of Western missionaries' (Banda 2005:5). It is contended that the Western missionaries then imposed their world view upon African people 'mainly at a presuppositional level' (Bosch 1993:292). The missionaries presented Jesus Christ in a way that depicted him (Christ) as a Westerner in identity (Aguwa 2007:127-128; Ezigbo 2008:2-17; Setiloane 1976:89; Taylor 1963:16).

The above situation resulted in African Christians having difficulty in trusting Christ's ability to intervene in their life challenges that require healing. Banda (2005:27) laments that 'this is a Christological indictment, for Jesus is the essence of Christianity', as Christianity anchors on Christ. The indictment observed by Banda (2005) begs the question of the link between Christology, which is the very essence of Christianity, and practical life. The discussion of Christology has been largely considered from a systematic theological perspective without drawing clear and explicit links and implications to practical life. For instance, a considerable number of African theologians have grappled more with the problem of the foreignness of Christ in African Christianity by translating the gospel into traditional African categories and concepts that are familiar to African Christians (Igba 2013:3; Orboji 2008:15-17) and much less with the implication and link of Christology to practical theological issues. This method 'reflects on the gospel, the Christian tradition, and the total Christian reality in an African manner and from the perspectives of the African world view' (Orboji 2008:15). Some of the approaches that have been employed by African theologians in attempting to make Jesus Christ familiar and relevant to Africans include the treatment of 'Jesus as the liberator, the ancestor, the healer, the African king and the African chief' (Orboji 2008:16). 
However, the treatment of Christ as an ancestor is the predominant approach that African theologians follow (Orboji 2008:16; Wacheche 2012:27). Bediako (1994:93-121), Bujo (1992:79), Nyamiti (2006:24), Pobee (1979:94), Milingo (1984:85), Kwesi (1984:197-198), Kabasele (1991:123-124) and many others approach the subject of Christology from an ancestral perspective. Orboji (2008:15) argues that 'in the writings of African Christian theologians, one sees the effort to link the African ancestors' world view with the selfrevelation of God in Jesus Christ'. Perhaps this approach has gained popularity in the academic literature, because for Christ to be accepted by Africans and fulfil the expected responsibilities in addressing African contextual needs (which are believed by some Africans to be the role of ancestors and other African traditional practitioners); the overarching concern is about the familial relationship between Jesus Christ of Nazareth and the African people, since the two do not belong to the same 'clan, family, tribe and nation' (Bediako 2004:23). Thus many African Christians do not know 'how the Jesus of the Church's preaching saves them from the terrors and fears that they experience in their traditional world view' (Bediako 2004:23).

The treatment of Christ under the ancestral concept takes the traditional African ancestral world view seriously. Nevertheless, this approach has encountered serious critiques at both academic and grassroots ${ }^{1}$ levels. Scholars who are opposed to the treatment of Christ under the category of ancestors argue that this approach reveals a tendency to diminish the actuality of Christ as God incarnate and to encourage syncretism in African Christianity (Mkole 2000:1138; Palmer 2008:65-76; Reed \& Mtukwa 2010:144163). Concerning the diminishing of Christ as God incarnate, these theologians are of the opinion that since Christ is God incarnate, he transcends the African ancestor category. This makes the concept of ancestors unsuitable for a biblically based Christology. Concerning syncretism, they argue that it is unhelpful to force the preconceived African ancestral category on Christ, since it encourages African Christians to continue to think of Christ in the category of their natural ancestors. That is, the conceptualisation of Christ in the ancestral concept encourages African Christians to perceive their natural ancestors as intermediaries between themselves and God (Reed \& Mtukwa 2010:157).

The above position shows us that there are limited models that are applicable and relevant in African Christology, which affects Christian pastoral care and healing ministry. The challenge and need for responsive models is central to Christian ministry and pastoral ministry as a practical life ministry. There is a need for theory formation that is contextually relevant to Africa but maintains a clear Christian healing perspective without compromising authentic Christianity. Theory formation should be relevant and applicable to engage and address people's life challenges. Louw (1998:20-23) rightly advises that linking theory

1.Palmer (2008:65) similarly contends that many Protestant and Catholic theologians 'have referred to Jesus as an ancestor. Yet at the grass-roots there is still significant resistance to such a concept'. (doctrine) to life, religious resources to practical realities and spirituality to life experiences are some of the greatest challenges of theology, particularly practical theology. It is imperative therefore to explore fresh models that provide practical effective ministerial approaches in Africa, particularly within the context of healing and pastoral care. Given this, this article is an attempt to explore fresh models that provide practical effective ministerial approaches in Africa by establishing an Adamic Christological practical theological imagination for healing. In order to accomplish this objective, the article firstly gives a brief understanding of pastoral healing. Secondly, it establishes Adamic Christology as a nexus anchor for an imagined practical theology. This entails defining Adamic Christology by using Luke 3:23-4:13 and Hebrews 2:5-18 to establish Adam as a foundational biblical category, which can be used for the purpose of enhancing Christ's identification with African Christians (identification model). However, because Adam is not a category that arises from the traditional African world view or culture, the article provides a critical analysis of the Adamic Christological category in ensuring the complete identification of Christ with African Christians. The final section establishes a responsive ministry anchored on Adamic Christological practical theology, namely, Christ's identity with humanity and implications in life.

It is noted in the discussion that the ascension of Christ can confront African Christians with a possible misconception of God's discontinuous identification with them in their suffering at this interim period of Christianity. This issue is resolved by arguing for God's ongoing solidarity with believers in their suffering through the Holy Spirit (pneumatology). God's personal presence in believers' suffering through the Holy Spirit is presented as an encouraging and comforting reality that should enable Christians to cope in their suffering. Because of God's presence in Christians' lives through the Spirit (pneumatological being), African Christians may claim complete solidarity with God everywhere in their moments of suffering and hold faithfully to Christ's promises in the scriptures (promissiotherapy). In advancing this argument, we posit a model for African Christians' daily response to their various contextual sufferings. It is envisaged that this model will empower African Christians to cope within their various moments of suffering without compromising their Christian hope and standing.

\section{Towards an understanding of Christian and pastoral healing in suffering}

There is an interconnection between healing and salvation (De Gruchy 1989:39). In De Gruchy's (1989:39) view, healing cannot be separated from the notion of salvation. Jesus and the early Christian community's healing ministries were integral for the proclamation of the kingdom. In this way, pastoral care as a healing ministry is grounded in Jesus Christ, the very God himself, who went through Galilee 
healing every disease and affliction (Mt. 4:23). Theologically, the diseases and afflictions kept humankind captive to the world that bears the corruption that came through the first Adam (Rm. 5:12-21). Bowden (2005:1112) thinks that our understanding of sickness and healing in the Christian tradition should be rooted in Jesus' ministry. His reason is that almost $40 \%$ of the gospel narratives are dedicated to describing Jesus' healing deeds. Likewise, Magezi (2007:757) argues that in pastoral care, Jesus and salvation are central pieces of the puzzle in pursuit of healing. He stated that 'the story of salvation is linked to the story of parishioners' struggle, agony and suffering' (Magezi 2007:757). This indicates that healing in the Bible reflects a holistic understanding of humanity and reality, as De Gruchy (1989:39) noted. De Gruchy (1989:39) linked salvation, healing and shalom by maintaining that the concept of shalom is not only about the psychic and physical dimensions of a human being but also about the social and political order. In making this assertion, De Gruchy (1989:39) is clearly connecting salvation and healing as those processes that enable us to be fully human in relation to our society, our environment and ourselves. Both salvation and healing are indicators of healing and humanisation. The Bible reflects a holistic understanding of humanity and reality. Thus, healing cannot be separated from the notion of salvation and peace (shalom).

Drawing a link between healing and pastoral care and ministry, Hunter (1995:18) states that pastoral care and counselling are conceived as a healing art, and the field as a whole has taken health and healing as its primary metaphor for a personal caring ministry. Louw (2008:11) added that pastoral care is about healing and cura vitae (the healing of life). Healing is about being connected to Christ (soteriology), which revitalises life and makes it meaningful and purposeful (as a pneumatological being). This way pastoral care is connected to Christology, salvation and healing. Louw (2014:35) clarifies that the interplay of these concepts indicates the resources that should be invoked within the art of Christian healing during life's existential challenges. Therefore, in engaging in African Christian healing ministry, one should understand that the salvation by God in and through Jesus Christ encompasses both physical and spiritual dimensions. Indeed, there is no need to limit Christ's salvation to sin or the soul as some early Western missionaries did during the early missionaries' era of Christianity in Africa (Aho Ekue 2005:104; Mbiti 1986:158-159).

Salvation in God is all-encompassing, including both the material and spiritual reality. Louw (2003:213) rightly explains that pastoral healing is about salvation. ${ }^{2}$ The term cura animarum means 'cure of souls' and the soul is the qualitative principle of life (nefesh) as displayed within a very specific disposition or condition before God (pneumatology). Therefore, it is maintained that theologically, healing refers to the event of being transformed from a condition of death into but as the ongoing process of 'being saved', which continues into eschatological resurrection existence. a condition of life (soteriology). This new condition is an indication of a new state of being (pneumatological being): being accepted unconditionally by grace and being restored into a new relationship with God (soteriology), a relationship of peace, reconciliation and forgiveness (shalom and healing). This implies soul healing. Soul healing in pastoral care thus refers to pastoral acts and intentions that emanate from salvation. It opens up new avenues of understanding our human vocation. It also refers to a sense of direction, which instils meaning and reflects the contextual implication of the gospel for life issues. Louw (2014:11) clarifies that this state entails innovatively exploring the implications of salvation and Christ in life's situation to get meaning. A pneumatological being is a spiritual innovator who draws from spiritual resources and the reservoir of salvation for healing and coping in times of crises and challenges. Healing, therefore, is that which enables us to be fully human in relation to our society, our environment and ourselves. Healing, salvation (soteriology) and shalom are dimensions within a pneumatological person that interplay to foster Christian pastoral healing. These dimensions are anchored on Christology. Without the Christological anchor they are empty and lack substance. This Christological anchor can arguably be described as Adamic Christology.

\section{An Adamic Christological nexus for a practical theological imagination}

An Adamic Christological framework can be advanced from Romans 5:12-21 and 1 Corinthians 15 as key biblical texts. These texts provide a foundational biblical-theological basis for Adamic Christology. However, in this article, we use Luke 3:23-4:13 and Hebrews 2:5-18 as an unusual nexus in establishing the biblical-theological foundational status of Adamic Christology. The following sections utilise Luke 3:23-4:13 and Hebrews 2:5-18 to establish Adamic Christology as a foundational biblical category that can be used for the purpose of enhancing African Christians' understanding of God's complete identification with them in Christ to achieve pastoral healing. The examination of Adamic Christology from these two selected texts is important for two reasons. Firstly, it indicates how pervasive Adamic Christology is across the New Testament, not only in Paul's writings. Secondly, it identifies the many and different elements in the person and work of Christ that are evident in Adamic Christological outline.

The above understanding arises from the fact that the scripture presents Adamic Christology by drawing comparisons between Adam and Christ, either explicitly (cf. Rm. 5:12-21; 1 Cor. 15:21-22, 45-49) or implicitly (cf. Lk. 3-4; Heb. 2:5-18). In the comparisons between Adam and Christ, there is an ontological inclusivity of all humankind in their vicarious humanity. Here, Adam stands as the head of fallen humanity, while Christ stands as the head of redeemed humanity. Moreover, Adam is a type of Christ, who is the real thing (the anti-type), which this type symbolises (cf. Rm. 5:14) (Barth 1956:9-10; Hultgren 2011:226). That is, even though there are continuities between Adam and Christ on 
the basis of the corporate solidarity of humankind in their vicarious humanity, the God-man, Jesus Christ (Christology) exceeds Adam in all respects as the one who undoes Adam's sin and death for all humankind who believe in his saving person and work (soteriology and Christological connection).

\section{Adamic Christology in Luke 3:23-4:13 and Hebrews 2:5-18}

Luke's genealogy presents Jesus Christ as 'the son of Adam, the son of God' (cf. Lk. 3:23-38). This was aimed at Jews and Gentiles to make them embrace Jesus Christ as their own true saviour $^{3}$ (Marshall 1978:161). Marshall (1978:161) comments that 'the carrying back of the genealogy to Adam is meant to stress the universal significance of Jesus for the whole of the human race and not merely for the seed of Abraham'. For the purpose of this article, it does not matter whether Luke's Gospel was written to assure those who had heard and believed the gospel of Jesus Christ or to evangelise those who had never heard the gospel. ${ }^{4}$ Our concern is that Luke is deliberately linking Jesus' genealogy with Adam in order to show the inclusion of both Jews and Gentiles in God's salvific plan, fulfilled by the true man Jesus Christ, who is the true biological offspring of Adam (Ryken 2009:143-149).

In formulating Adam's Christology in Luke, Ryken (2009:145148) points out some interesting dissimilarities between the Gospels of Luke and Matthew. On the one hand, Matthew is interested in establishing that Jesus is the true Davidic heir of the throne of David. Matthew does this by mentioning 'the rightful heirs to Israel's throne' in commencing his genealogy with a discussion of Abraham and David and then ending up with Jesus Christ as the true Messiah for Israel, who is the true offspring of both Abraham and David (Ryken 2009:145). On the other hand, Luke is interested in establishing both the real divinity and humanity of Christ by tracing him as 'the son of Adam, the son of God' (cf. Green 1997:188-190). Luke 'traces Christ to David's son, Nathan, through his actual mother Mary, through whom he can rightfully claim to be fully human, the redeemer of humanity' (Ryken 2009:147148). In other words, by naming Jesus Christ as the son of Adam, Luke is moving towards his affirmation that 'Jesus Christ was into our race as a human among men' (Ryken 2009:143). That is, Jesus Christ is the true descendant of Adam, who stands as the fulfilment of the first obscure gospel promise of Genesis 3:15, since he crushes the devil through his saving incarnation, life, death and resurrection and therefore reconstitutes a new faithful covenant community comprised of both Jews and Gentiles (Bock 2012:42).

Furthermore, this Adamic Christology ${ }^{5}$ stems from Luke's deliberate comparison of the disobedience of Adam and the obedience of the God-man, Jesus Christ. Both Adam and

3.Stein holds a different view to Marshall. He argues that even though Luke might have had some Jews in mind, his primary audience was Gentile (Stein 1973:26-27).

4.This purpose is the one that Marshal (1978:35) holds as the evangelistic purpose of Luke, that is, 'the presentation of the ministry of Jesus in its saving significance'.

5. Here, we are not saying that Luke was primarily concerned with establishing Adam's Christology. That is, we are of the same opinion of Culpepper (1995:95), who understands that Luke was not mainly concerned '... with a second Adam Christology but with the affirmation that Jesus Christ was the son of God'.
Christ have a unique relationship with God as two different sons of God $^{6}$ (Ryken 2009:148-149). The first Adam was not of human generation; instead, he was 'created in the image of God', which implies that 'Adam bore the likeness of God' as the son of God (Ryken 2009:148). This first son of God was tempted by the serpent in the Garden of Eden and fell into sin, which corrupted the whole human race. In this way, Dunn (1989:112) is right in using the Adamic fall of Genesis 3 to maintain that Luke (3:38) presents Adam 'as the son of God whose sonship was destroyed by the fall'. Luke is interested in Jesus Christ as both the 'Son of Man' (the son of Adam) (cf. Lk. 19:10, 9:58 \& 7:34) and the divine Son of God, in whom God the Father at his baptism was well pleased with his Son (cf. Lk. 3:22 \& Lk. 9:35, which echoes Is. 42:1). In this way, Luke confronts all humankind with Jesus Christ as the New Adam, who is both divine and human in nature (Ryken 2009:143, 148-149). He is both the true Son of Adam and the true Son of God, ${ }^{7}$ who knew no sin but chose to identify himself with sinful humankind in the incarnation and proceeded to volitionally identify himself with the sinful nation of Israel in the act of John's baptism of repentance ${ }^{8}$ (Lk. $3: 22$ ). Soon after that he ventured into direct conflict with his enemy (the devil) in the wilderness, winning an overwhelming victory there (Lk. 4:1-13, cf. Mk.; Mt. 4) (Ryken 2009:133, 151163; Seccombe 2002:90, 132-133). Therefore, by bringing Adam, the failed son of $\operatorname{God}^{9}$ (cf. Lk. 3:38) in the Garden of Eden (cf. Gn.s 3) to bear in this comparison, Jesus Christ is portrayed as the true Son of Man and God, who succeeded where the first Adam had failed by living a life of active and passive obedience to God the Father unto the point of death at the cross for the salvation of all mankind.

In view of the above:

Luke sets the life of Jesus both in its historical context and a theological context. All that happens in the Gospel ... is ultimately a part of God's redemptive plan for the salvation of all humanity. (Culpepper 1995:20; cf. Green 1997:21)

Therefore, we observe, in agreement with Bock's (2012:68) assertion, that Luke $4: 1-13$ is a crucial passage that ends by showing that Jesus is worthy 'of being the second Adam' through 'enduring and surviving temptations from Satan'. From Luke we turn to the book of Hebrews 2:5-18.

Hebrews 2:5-18 is a crucial passage in which Adam's Christology is implicitly stated (Hagner 2005:247-253). In

6.5 eccombe $(2002: 123$, cf. Torrance 1992:36) is of the conviction that the sonship of both Adam and Jesus is related to their appointment to rule the world, and their both Adam and Jesus is related to their appointm
testing is an attempt to subvert this appointment'.

7.Marshall (2005:123) argues that the question of the coexistence of the Son with the Father is not addressed explicitly; however, this does not mean that Luke does not implicitly uphold the pre-existence of Christ.

8.For a detailed discussion of the purpose of Jesus' baptism, see Seccombe's (2002:90, cf. Ryken 2009:133) discussion in his systematic approach to the Gospels, in which he concludes that Jesus' baptism identifies him with sinners. He '... felt a bond of unity with his people which made him unwillingly to stand aside from their corporate guilt as a nation, and therefore made his standing with them in baptism appropriate'.

9.At this juncture, Israel as the failed son of God in the wilderness is also contrasted 9.At this juncture, Israel as the failed son of God in the wilderness is also contrasted
with Jesus Christ, the successful son of God. Israel was God's chosen son (cf. Hosea 11:1) but she failed in her temptation in the wilderness (cf. Nm. 10:11-14:45). That 11:1) but she failed in her temptation in the wilderness (cf. Nm. 10:11-14:45). That
is, we have the two failed sons of God (Adam and Israel) in comparison to Jesus Christ, the faithful Son of God. 
bringing the wider context of Hebrews to bear on the theological construction of Adamic Christology, Hagner (2005:247) rightly affirms that this epistle was written to a Christian community facing multifaceted challenges that were causing them to consider abandoning their Christian faith. Even though these Christians had not suffered to the extent of shedding blood for their faith (Heb.12:4), the author indicates that 'some members had been imprisoned, and others suffered the confiscation of their property' (Heb. 10:34) (Craddock 1998:9). These challenges are amplified by the author's use of words such as 'persecution' (Heb. 10:33), 'hostility' (Heb. 12:3) and 'torture' (Heb. 13:3) (Craddock 1998:9). However, it is surprising that the author of Hebrews responds to his audience's challenges by providing a thorough discussion of the person ${ }^{10}$ and work of Christ (Craddock 1998:10; Hagner 2005:247-248). This seems to suggest that 'at the heart of their problem was inadequate Christology for their social context' (Craddock 1998:10). The audience of Hebrews might have had a high view of the divinity of Christ at the expense of his humanity or vice versa. ${ }^{11}$ With this in mind, the author finds it necessary to bring his implicit Adamic Christology in Hebrews 2:5-18 as a means of deepening his audience's understanding of the saving significance of the incarnation, death and exaltation of Jesus Christ 'into the larger scheme of God's redemption' (Craddock 1998:10).

Hebrews 2:5-18 brings Adam's role in its quotation of Psalm 8:5-7. Even though commentators may disagree ${ }^{12}$ about the author's usage of Psalm 8:5-7 in Hebrews 2:5-8, Dunn (1989:109) and Hagner (2005:248) offer a plausible interpretation in suggesting that in its original meaning, Psalm 8:5-7 reveals God's intention for humankind. Human beings are created lower than the angels yet crowned with glory and honour, which they forfeited in the fall of Genesis. ${ }^{13}$ That is, the Psalm is reminiscent of the Genesis (chapters 1-3) narrative of creation and fall, in which we perceive Adam as the representative of all humankind crowned with honour and glory (Hagner 2005:252-253). Here, God also made all of creation subject to Adam, as ruler on his behalf (Craddock 1998:42-43; Jewett 1981:42-43). Hence, Craddock (1998:37) argues that the psalmist:

... offers praise to God and contrasts the power and majesty of God with the relative insignificance of human beings. It ponders

10.The epistle of Hebrews confronts us with the reality that because of his deity and humanity, Jesus Christ is both the Son of God and high priest and therefore he is hum able to make a single offering for sin that is fully efficacious for all time' (Hagner 2005:248). Even though the author of Hebrews set forth the pre-existence of Christ as the basis of his superiority over the Old Testament prophets and the understands that both the divinity and humanity of Jesus Christ have salvific significance for 'the finality of God's work' in him (Hagne 2005:247-248).

11.We agree with Craddock (1998:10) that the recipients of the letter of Hebrews possibly had an inadequate understanding of the salvific significance of the '.. exaltation and enthronement of the Son'. That is, their understanding of the exaltation and enthronement of Jesus did not give them the knowledge of Jesus Christ's ongoing intercessory ministry for believers.

12. For example, Craddock (1998:37) seems to dismiss the possibility of Adam's Christology in Hebrews 2:5-18 in his argument that: 'it does not seem appropriate here to elaborate on possible second Adam or Son of man Christologies embedded in the text. Neither is developed in Hebrews and therefore, would require heavy borrowings from the gospels and Paul'.

13. Even though we have questioned Dunn's construction of Adamic Christology in Philippians 2:6-11, we continue to use his establishment of Adamic Christology in Hebrews 2:5-18 and Romans 5:12-21, because it corresponds with the biblical data. why God would think of humans. The Psalmist does not lament human frailty but reaffirms the unique place of humanity in relation to God and the rest of creation. (cf. Genesis 1:26:28)

Now with reference to Jesus, the author of Hebrews is depicting Jesus Christ as the 'archetypal human' (Hagner 2005:253). That is, Hebrews 2:5-8 is quoting Psalm 8:5-7 as an affirmation of Jesus Christ's true identification with humanity in the incarnation, as the second Adam who restores God's purpose for humankind, which was corrupted by the Adamic sin and its consequences for all humanity.

Even though in this interim Christian period believers do not yet see all things subjected under Christ's feet (Heb. 2:8) as the New Adam, it is clear that in the incarnation, God in and through Jesus Christ successfully embarked on a mission of saving mankind (Heb. 2:9-15) (Ellingworth 1993:148-157). God accomplished the salvation of humankind in and through the incarnation of Jesus Christ, in which he was made 'a little lower' than the angels (Hebrews 2:8b) by assuming our actual flesh and blood as the second Adam, destroying the devil who holds the power of death and therefore liberating humankind, who were in bondage to the fear of death (Heb. 2:14) (Ellingworth 1993:153-179). Jesus Christ was able to taste death for all humankind (Heb. 2:9a), because he was made like us in every detail (Heb. 2:17a) with the exception of sin and therefore suffered death for the propitiation of our sins (Heb. 5:17b) (Ellingworth 1993:170179; Ryken 2009:149). Craddock (1998:39) maintained that 'any life short of suffering and death would have been less than identification with humankind, and therefore, less than a full understanding of the human condition'. To bring the entire Christological argument of Hebrews to the fore, we argue that Jesus Christ is the true God-man, the author and perfecter (Heb. 2:10) of the salvation of humankind, who vicariously suffered death for everyone and was crowned with glory and honour at his exaltation after death (Dunn 1989:109). In this way, all Christians are exhorted to have their confidence in Jesus Christ as the sole merciful and faithful divine-human high priest, who is qualified to minister the things of God to man and the things of man to God. We are warranted to have the aforesaid understanding of Christ's salvation for humankind, because:

\footnotetext{
... the divine programme which broke down with Adam has been run through again in Jesus - this time successfully. It was by playing out the role of Adam that Christ became the last Adam: Adam led man to death and not glory, but Jesus by his life, suffering and death became the pioneer, opening up the way through death for those who follow him. (Dunn 1989:110)
}

The above discussion of Luke 3:23-4:13 and Hebrews 2:5-18 indicates that an Adamic Christology is a justifiable mediating category that can be employed for Christian ministry, particularly pastoral care in Africa, which is the context of our discussion. It helps African Christians to understand Christ's full solidarity with them in their suffering. However, a question that emerges is: What is the link between Adamic Christology and practical ministry, particularly in Africa? Central to this question is the relevance of the Adamic 
Christology to practical theological reflection. At stake is the question: Can a practical theological approach that hinges on Adamic Christology be justifiably advanced and sustained within an African pastoral care and healing context? The next section seeks to address these questions.

\section{An Adamic Christology as a practical theological imagination: Towards identification of Christ with African Christians}

In a recent collection of essays by leading practical theologians titled Opening the Field of Practical Theology, edited by Cahalan and Mikoski (2014:1), the authors identified at least 11 elements that integrate and guide the work of practical theologians across a variety of contexts: one of these elements is holistic. The authors maintain that practical theology is about experience. However, human experience is not limited only to ideas and the life of the mind but involves other features. These features include imagination (Cahalan \& Mikoski 2014:3). Certainly imagination involves an array of things such as interpretation, reflection and even dreaming of alternative ideal situations in a broken world. Louw (2008:17) in Cura Vitae: Illness and the Healing of Life explains that practical theology deals with the 'praxis of God as related to the praxis of faith within a vivid social, cultural and contextual encounter between God and human beings'. Practical theology entails discerning God in a real world. This then calls for invoking Christian and spiritual resources to explore and imagine fresh and alternative perspectives of coping in life. It is not about a dry theology that does not impact and impart practical life. Viewed this way theology, particularly practical theology, is a life science. It is about practical knowing not theoretical or abstract knowing. Fowler (1983) aptly captures practical theology as a life science in the following way:

Practical theology aims at a kind of knowing that guides being and doing. While concerned with theory, it is not theoria; while concerned with techniques, it is not poesis. Its knowledge is a practical knowing - a knowing in which skill and understanding cooperate; a knowing in which experience and critical reflection work in concert; a knowing in which disciplined improvisation against a backdrop of reflective wisdom, marks the virtuosity of the competent practitioner. (pp. 154-155)

Thus practical theology is about utilising the Christian knowledge to shape and inform practical life. It entails continuous imagination of what it means to live a whole life in the world. It is about innovatively utilising the available faith resources to cope in a complex and uncertain world. It is about continuous reimagination of what it means to live meaningfully, wholly and purposefully in a complex situation. In other words, from a practical theological perspective, theology should continuously explore fresh perspectives about coping with life as well as living whole lives. Louw (2014:35) in his recent book Wholeness in Hope Care: On Nurturing the Beauty of the Human Soul in Spiritual Healing draws a clear link between wholeness, salvation, faith, healing and life. He stated that 'wholeness is about the integration of faith and life, body and soul, salvation and healing, creation and affirmation, divinity and humanity' (Louw 2014:35).

Considering pastoral care and counselling as a practical theological science, it should be viewed as fides quaerens intellectum (relational reflection and theory formation), fides quaerens verbum (language, words and communication), fides quaerens actum (action and transformation of the individual) (Louw 2014:35). In this way, practical theology is an art and life science. In view of this, a doctrine such as Adamic Christology and its implication and relevance to people's lives could be a pivotal doctrine. It provides a clear theological reflection and language resulting to action and transformation. This occurs through an effective practical theology that employs a hermeneutics of continuous imagination. In this regard, Louw (2014) advises that:

Practical theology and Christian spirituality is about hope: (fides quaerens spem: faith seeking hope) and anticipatory imagination: (fides quaerens imaginem: faith seeking imaginative deciphering). Hope constitutes a critical praxis of engagement with painful transience as well as a transformative praxis of anticipatory renewal and change. (p. 11)

This implies that hermeneutics (interpretation) and gaining insight into a situation is critical. Insight should lead to innovative and creative exploration resulting in forging new frontiers and approaches that lead to healing and coping. Viewed this way, doctrines drawn from normative sources such as Adamic Christology and practical life are intrinsically linked and integrated as one in assisting people to cope with life. In this way, theology and doctrine become tools and apparatus utilised as creative resources for healing in life. They are resources drawn from the art of life and coping (i.e. theology and particularly practical theology as a life science).

In view of the above discussion, a biblical-theological understanding of an Adamic Christology can be identified at a theoretical and reflection level within African pastoral care and healing. An Adamic Christology could be advanced as a mediating category in helping African Christians to understand Christ's full solidarity with Africans in their suffering. However, we are also aware of the possible objections that may be raised against employing Adam as a mediating category in communicating Christ's complete solidarity with African Christians in their innermost existential challenges. It can be rebutted that the Adamic category is a mediating concept, which does not arise from traditional African culture or world view. Therefore, how can it be legitimately employed to aid African Christians to understand Christ's complete identification with them? In responding to this challenge, we argue that there are limited African traditional categories that can be applied to Christ as a means of enhancing his (Christ's) complete identification with African Christians without undermining his (Christ's) supremacy as God incarnate. Moreover, we have not encountered a mediating category in traditional African culture or world view that can be employed to best describe Christ's complete identification with African believers without encouraging syncretism. 
We maintain that, although the traditional African world view has to be taken seriously, world views or cultures must not be exalted at the expense of clear gospel ministry that results in pastoral healing. All cultures must be 'treated with dignity and respect in a theological process' (Cortez 2005:356). However, owing to the universal pandemic of $\sin$ (Rm. 3:23), all cultures are 'fellow participants in the theological endeavour but not as an epistemological conclusion in which we assert the complete validity' of our hypothesis of contextualisation (Cortez 2005:356). Hence, it is not necessary to compel the traditional African concept of Christ as an ancestor [as Bediako (2004) did], since it cannot retain the being of Christ as God himself. The presentation of Jesus Christ under the ancestral category (in African Christianity) 'might only serve to further an existing practice by providing some sort of validation for an existing culturally relevant but non-Biblical practice' (Igba 2013:124). Dualism and syncretism can only cease in African Christianity by the exaltation of Jesus Christ over the world of spiritual powers, as Salala (1998:138) noted. Salala (1998) stated that:

Unless Christ is elevated in the person's cosmology as he is in heaven, dualism persists, syncretism is advanced, and Jesus is reduced to being simply an additional helpful source of power, perhaps equal in power with traditional spirits and personalities. (p. 138)

Further, many African theologians (such as Bediako 2004:25; Nyamiti 2006:12) mention Adam in their biblical discussions without saying much about the major difficulties of African Christians in understanding their real solidarity with Adam. This silence in African scholarship could imply that African Christians do not struggle to understand their corporate sinful solidarity with Adam, the forefather of all humankind. That is, African Christians understand that 'every member of the human race is descended from the biblical Adam', which is a 'standard doctrine in Islamic, Jewish and Christian thought' (Livingstone 2008:5). However, even though one could argue that African Christians do not consider the importance of their complete identification with the biblical Adam, because they are not much preoccupied with sin as the root of their existential challenges, it does not seem that we have any basis for that reasoning. Bediako (2004:25) noted that Africans are much more concerned with the need for a saviour from a realm beyond who fully identifies with them and saves them from their insecurities. Given this, if African Christians do not find significant difficulties in understanding Adam's identification with them, then an Adamic Christology that views Christ as our New Adam is the next and necessary step in enhancing African Christians' understanding of Christ's complete solidarity with them to the extent that they can solely rely on him in the midst of their African contextual sufferings that require healing.

That is, instead of African Christians' continual reliance on their traditional African familial mediums in addressing their contextual sufferings that require healing, they can be empowered through practical knowledge to fully rely on Christ's ability to address their spiritual insecurities and sufferings as their New Adam, with whom they are united by faith. African Christians' identification with Christ in Adamic Christology therefore provides a practical theological imagination that engages the African context. It provides a reflection framework that would result in creative healing. It becomes a relevant language and communication (fides quaerens verbum) that would result in action and transformation (healing and coping).

\section{Towards a responsive ministry anchored in Adamic Christology Christ's identification with humanity and its implications for pastoral healing}

Even though salvation in our New Adam encompasses all aspects of life (i.e. both material and spiritual reality), the ascension of Christ confronts us with the notion of continuity and discontinuity between the present world and the world to come (Farrow 1999:46). In his book Ascension and Ecclesia, Farrow $(1999: 40,43)$ summarises this existing continuity and discontinuity. Farrow (1999:40) argues for the existence of two histories in scripture, namely, world history and covenant history. In the wider argument of his book, Farrow contends that through Jesus' ascension, world history and covenant history are now separate in our view, although world history is still ultimately determined by covenant history. Concerning covenant history, Torrance (2009:294) showed himself to be in line with Farrow by his contention that the ascension of Christ is the ultimate end of creation and redemption revealed in the covenant of grace and fulfilled in Jesus Christ'. In other words, covenant history has 'already reached its goal' in Christ's ascension, and yet it is now out of our sight in heaven, where Christ is seated at the right hand of God the Father (Farrow 1999:40). However, world history continues in this present era of Christianity, and believers are to continue to live in this world history without conforming to its observable sinful patterns (Farrow 1999:43).

This brings us to the existential tension that even though believers are part of the covenant history in their hypostatic union with Christ (through faith; Col. 3:3), they continue to exist in the midst of the observable patterns of this ongoing history of the world. However, in their continual existence within this world history, Christians are supposed to 'live in the power of the resurrection as those who are united to the risen Jesus Christ', and they 'must not be schematised to the form of the secular world but must be transformed through the renewal' of their 'mind in Christ' (Torrance 2009:247). In other words, in this ongoing history of the world, Christians are to live as the already renewed people of God, waiting for the second coming of Christ in order to bring his final restoration of all creation (Torrance 2009:256). That is, within the nature and extent of Christ's salvation, Christians are living in an interim period in which Christ's salvation in all aspects of life is partially realised (Heb. 2:8). It is so since they are waiting for the complete acknowledgment of his reign by all creation at his second coming to make all things entirely new. Louw (2008:12) refers to this as 'eschatological thinking' that should be possessed by pneumatological beings 
(Christians). Torrance (2009) summarises the aforementioned existing tension in this way:

The ascension also means that this time of the new creation in Christ is hidden from us, and, as it were, held back from us until in the mercy of God Jesus Christ comes again to judge and renew all creation. Nevertheless, it remains valid that in the risen Christ our human nature in its creaturely and temporal existence is redeemed and renewed and established through being taken up in its affirmed reality into the life of God. (p. 256)

However, because the ascension of Christ confronts us with a superficial discontinuity and continuity of God's complete solidarity with believers in their suffering in this Christian interim period, we resolve the discontinuity issue by arguing for Christ's sending of the Holy Spirit (Ac. 2:1-33). The New Testament and the early church:

... when the crucified Jesus rose again from the dead and poured out his Spirit at Pentecost, the intrinsic significance of his person and all he had said and done broke forth in its self-evidencing power and seized hold of the church as the very Word or Logos of God. (Torrance 1992:4)

With the dynamic presence of the Holy Spirit within Christians' lives, the ascension of Christ does not mean that God in Christ is distant from African Christians' suffering. That is, even though Christ is currently residing in heaven, the presence of the Holy Spirit affirms that God is not distant from African Christians' various contextual sufferings that require healing. This understanding avoids a separation between what God has done for us in Christ's historical redemptive work and where Christians are now at the moment, namely, in the now-but-not-yet era of Christianity (Horton 2011:557).

However, in arguing for the presence of God in believers' suffering through the Holy Spirit, we do not regard the ascension of Christ (Ac. 1:6-11 and Lk. 24:50-53) as an artificial historical event in the history of Christianity. This is because we maintain that the ascension of Christ is the entering of the uninterrupted hypostatic union between God and humanity into the eternal place of God in heaven (Torrance 2009:287-289). Once the aforesaid theology of Christ's ascension is clarified in our Adamic Christology, we unswervingly contend for God's continuous solidarity with Christians in their suffering through the dynamic presence of the Holy Spirit. That is:

It is through the Spirit that things infinitely disconnected disconnected by the 'distance' of the ascension - are nevertheless infinitely closely related. Through the Spirit, Christ is nearer to us than we are to ourselves, and we who live and dwell on earth are yet made to sit with Christ in heavenly places, partaking of the divine nature in him. (Torrance 2009:294)

That is, after the ascension of Christ, God continuously positions himself within African believers' existential and contextual life suffering, in which he addresses their needs according to his will. This is why Luke and John emphasise that the man Jesus Christ (our New Adam), the very God himself, is the one who gives the Spirit to those who are so deeply related to him as brothers (Heb. 2:5-18) and friends given to him by the Father (Jn. 10:29). In Luke, it is the ascended Jesus of Nazareth who sends the Spirit (Lk. 24:3649 , Ac. $1: 2-4 ; 2: 4)$. In John, it is the resurrected man Jesus who breathes his spirit into his disciples (Jn. 20:22). The truth is that when Christians have Jesus by faith, they have full assurance and full security that they have the Holy Spirit. This is counter to certain neo-Pentecostal claims that the gift and possession of the Holy Spirit is to be doubted without further experiences. Given this, in moments of suffering, it is both empowering and comforting for African Christians to know that:

We are not left on our own as far as our relationship with God is concerned; neither are we left on our own to 'slug it out in the trenches', as it were, with regard to the Christian life. Life in the present is empowered by the God who dwells among us and in us. As the personal presence of God, the Spirit is not merely some 'force' or 'influence'. The living God is a God of power and by his Spirit the power of the living God is present with and for us. The Spirit also empowers for endurance in the midst of adversity (Col. 1:11, 2 Cor. 12:9-10) and for everything else as we endure, awaiting the final glory, of which the Spirit is the guarantee. (Fee 1994:8)

In other words, God's dynamic presence through the Holy Spirit within the lives of believers is the fulcrum of Christians' confidence in their moments of suffering. The Holy Spirit is the very God, who truly identifies with Christians in their suffering and intercedes for them in the midst of their weaknesses and groaning ( $\mathrm{Rm} .8: 26-27)$. The intercessory role of the Spirit renders a great assurance for believers, which makes them confident in their prayers to God in the midst of their many and different kinds of sufferings and groaning(s) (in which they cannot express themselves in words to God), since the Spirit of God intercedes on their behalf in accordance to God's will (Rm. 8:26) (Dillon 1998:696-699; Fischer 2011:118-119). In this regard, African Christians are to be reminded that the role of the Spirit in prayer is to transform their groaning in accordance with God's will, and assuredly the prayers of the Spirit (on behalf of believers) are always answered by God, since the Spirit is God, who knows the will of God in all situations (Moo 1996:526-527; Schreiner 1998:446; Wright 2002:599-600). Given this, Romans 8:26-27 brings the assurance that the Holy Spirit will enable Christians to subdue their challenges. Calvin (1948) puts it this way:

Even though we are in every respect weak, and various infirmities threaten our fall, there is yet sufficient protection in God's Spirit to preserve us from falling, and to keep us from being overwhelmed by any mass of evil. (pp. 311-312)

This is why Paul guaranteed Christians (cf. Phlp. 2:13) God's enabling power for them (believers) to act and will in a way that corresponds to their new sanctified status in Christ in their Christian life. In Philippians 2:13, Paul's inventiveness is to place the superiority of the Spirit's action in believers' maturity into Christ-likeness, since God is the one who empowers Christians to undertake the life of obedience and righteous living in the midst of their existential and contextual 
life challenges of suffering that require a Christ redemptive response. Owen's (1965:237) observation in light of Philippians 2 is apt here:

The Holy Ghost works in us and upon us, as we are fit to be wrought in and upon, that is, so as to preserve our own liberty and free obedience. He works upon our understandings, wills, consciences, and affections, agreeably to their own natures; he works in us and with us, not against us or without us, so that his assistance is an encouragement as to the facilitating of the work, and no occasion of neglect as to the work itself. (v. 13)

\section{The responsibility and response of believers in suffering: A paradigm}

As the partakers of God's holiness in Christ, believers are obligated to live lives that are shaped by our New Adam (Jesus Christ) as the ultimate model (Ellington 1993:639). In the believers' pilgrimage (of maturing into the likeness of Christ), they are to pursue holiness (Heb. 12:14) under the dominant model of Christ's endurance of suffering for sinful humanity (Heb. 12:3) and the gospel promises (Ellington 1993:639-644; O'Brien 2010:460). The Christ-like model enables Christians not to 'grow weary or lose heart' in their multifaceted difficult times (Ellington 1993:639-644; O'Brien 2010:460). It is important to note that the Jewish Christians were to pursue their sanctified lives in Christ regardless of their undeserved adversities, which included imprisonment (Heb. 10:34, 13:3), segregation from the ordinary community (Heb. 11:37-38) and expectation of persecution (Heb. 10:36, 13:6), because of their faith in Christ (Heb. 10:32-34; 11:1-40 and 12:1-11) (Cockerill 2012:18; Ellington 1993:698). Nevertheless, in the midst of their undeserved sufferings, the author of Hebrews exhorted them to view their circumstances from God's perspective, since their suffering was not in vain. The co-heirs of the eschatological kingdom of God are expected to enter the path of Christ's suffering in order to partake in his future glory (Rm. 8:17; 1 Pet. 1:11; Kruse 2012:340-341; Moo 1996:505-506). Jesus himself validated suffering as part of Christian life when he guaranteed his disciples that they were going to encounter troubles in their Christian pilgrimage (Jn. 16:33). In this way, suffering is part of Christian life. However, in challenging circumstances believers are responsible for enduring and focusing on Christ, the New Adam, who truly identified with them in the incarnation and undertook their disgraces (Heb. 2:5-18) and ushered them (believers) into eternal fellowship with God. This is why Torrance (2008, author's own emphasis) argues that the great palingenesia is:

\begin{abstract}
...the great conversion of humanity to God, which receives its ultimate and eternal answer in the divine satisfaction and good pleasure when God the Father raised Jesus Christ from the dead, and forever affirmed the reconciliation and restored fellowship effected in the obedient life and death of his Son, thus placing it eternally beyond all the assaults of evil and all possibility of undoing. Thus the covenant will of God for fellowship with man was translated into eternal actuality. (pp. 119-120)
\end{abstract}

Sometimes God nurtures believers' moral purity through their excruciating moments, in a way that preserves them in order to fulfil an intended purpose in their lives (Rm. 8:28).
Here, patience and hope in the gospel promises are the encouraged believers' response under their sufferings and groaning (Rm. 8:25). This is because Christians must 'reflect in their life together, attitudes and behaviours that are consistent with their new relationship with God in Christ' (O'Brien 2010:472). In other words, African Christians are practically exhorted to resemble the functional character of patience, hope and perseverance in their lives by placing their central focus on Christ and the gospel promises, irrespective of their multifaceted sufferings. This is because the God who truly identifies with us as our New Adam and saved us from sin and all its consequences ${ }^{14}$ does not take our suffering away instantly, whether it is physical or emotional pain. The God who truly identifies with us in our suffering helps us to endure the various sufferings so that we can learn to trust him more. In this way, it is appropriate to argue that God uses suffering in the lives of believers to progress their holiness in Christ (Atkinson 1995:90; Olagunju 2013:116). Therefore, in the context of suffering, African Christians should hold on to the New Adam (Jesus Christ), who is the ultimate fulfilment of God's unchanging gospel promises (2 Cor. 1:20).

To put it differently, African Christians have to hold onto Christ even when they are in hard times. This is possible by remembering the gospel promises (promissiotherapy), knowing that God will never change his mind; he will deliver us. However, even if God can chose (according to will) not to deliver us from our suffering at this interim era of Christianity, we are certain that through faith in Jesus Christ our salvation is eternally secured. This is in agreement with Atkinson's (1995) affirmation that:

... there is the need for us to have a view of suffering which acknowledges both its pain and its goal. There can be a pain which heals, a suffering which is sharing in the suffering of Christ. (p. 90)

Our New Adam, Jesus Christ, is the very God himself, who has overpowered the world for us through his redemptive acts (Jn. 16:330). This salvation should be understood in view of the eschaton.

In affirming the above-mentioned scenario, we are bringing forth the idea of suffering as formative or shaping Christian maturity in Christ. In avowing this, we concur with Olagunju (2013:116) that the Bible does not view God as the initiator of suffering; instead, the God who truly identifies with us in Christ uses 'those experiences as instruments of discipline, tests and as a means of growth' (Rm. 5:3-5; 1 Pet. 1:6-7). Thus, the Bible confirms that Christians' growth to maturity encompasses their acceptance of the actuality that 'suffering produces perseverance, perseverance character, and character hope, and the power of God being revealed in our weakness' (Rm. 5:3-4; 2 Cor. 12:9; Olagunju 2013:116). However, in the context of African Christians' suffering and trials (Ja. 1:2-4), God reminds them that he is still a loving and caring God.

14.This salvation from sin and all its consequences has to be understood in the interim Christian period, in which believers still encounter various challenges as they are awaiting the second appearance of their saviour, Jesus Christ, to consummate his salvation. 
This corresponds well with the Apostle Paul's (2 Cor. 4:17) argument that Christians' slight momentary troubles are achieving an eternal glory for them that is far beyond comparison with their present sufferings. Hence, African Christians are responsible for fixing their eyes on the invisible, eternal gospel promises and emulating the behaviour and character of Christ in their sufferings. This is because our New Adam, Jesus Christ, is the very God himself who truly identifies himself with African Christians and lived an obedient life to the Father. In this way, Jesus Christ:

\begin{abstract}
... became a model of the kind of godly life the Father wants to see in every Christian. He who was God in the flesh was able to manifest the kind of holiness of character in his attitudes, behaviours and interpersonal relationships that provided a concrete example of the moral image of God that he wanted to see restored in fallen man. Jesus became a demonstration of holiness with a human face, and by so doing became a model of life and character for everyone desiring to be remade in the image of the Holy One of the universe. (Coppedge 1980:93)
\end{abstract}

\section{Christ as suffering servant metaphor - empowerment for believers in suffering}

The metaphor of Christ (the New Adam) as a suffering servant who truly identifies with Christians in their various contextual suffering is both healing and empowering for believers. This arises from the actuality that Jesus Christ was truly God-man in nature. That is, as was contended in the council of Nicaea ${ }^{15}$ (of 325 AD), our New Adam is very much God himself (one in being with God the Father, cf. Jn. 10:30; Heb. 1:3, Col. 1:15-20; Jn. 1:1-5), who identifies with all humankind (in the incarnation) without ceasing to be truly God. In this respect, the incarnation 'constitutes the one actual source and the one controlling centre of the Christian doctrine of God, for he who became man in Jesus Christ in order to be our Saviour is identical in Being and Act with God the Father' (Torrance 1996:18). God's identification with all humankind in and through the New Adam (in the incarnation) is both vertical and horisontal in nature. The vertical nature of the incarnation implies the downward movement of the eternal, infinite and transcendent God in time, space and into the condition of human beings. The horisontal nature implies God's identification with all humanity in and through our New Adam in his incarnational mystery (Jn. 1:1-18). In other words, in line with the council of Chalcedon (in 351 AD), the vertical and horisontal nature of the incarnation implies that our New Adam (Jesus Christ) was fully divine-human in nature. That is, our New Adam comprises the uncompounded or unmixed divine-human nature, which implies that the fullness of both man and God (Col. 2:10) reside in the one eternal person of our New Adam, the eternal Son of God (Gunton 1992:47, 306; Torrance 2008:207).

Given this, in the incarnation, God in Christ truly identifies with humanity as the New Adam (Heb. 2:11-14) and knows what it is to suffer as a human being; hence, there is no human

15.For a detailed explanation of the Nicene formulation of the one being of God the Father and the Son, as well as the Chalcedonian doctrine of the unconfused true
divine and true human nature in the one person of the Son of God, see Need divine and true human natur
(2008) and George (2011). experience that is alien to God (Heb. 2:5-18). This is because our New Adam, Jesus Christ, is the very God himself, who 'has suffered when tempted'; therefore 'he is able to help those who are being tempted' or suffering (Heb. 2:18). Thus, African Christians can now have confidence that the Godman, Jesus Christ, has complete solidarity with them in their suffering, and he is able to bear with them in their suffering as the faithful and merciful high priest (Heb. 2:5-18). He (Jesus Christ) is the very God himself, who assumed our human mode of existence as the New Adam and fulfilled the prophecy of the suffering servant of Isaiah 53 (Bromiley 1982:645; Olagunju 2013:116). He underwent all the sufferings on our behalf so that he could bring estranged humanity back into eternal fellowship with God. In identifying with us in our human mode of existence, God in Christ faced all the testing and sufferings we face (yet he did not commit sin). Given this, Christians everywhere should be assured that through faith in Christ they have entrusted themselves to the power and realm of the merciful and faithful high priest who truly identifies with them in their sufferings; therefore, he is able to sympathise and heal them in their various contextual sufferings that require healing (Heb. 4:15).

The discussion above indicates that healing and hope in pastoral care is through knowing that Jesus Christ identifies with them in their sufferings as the merciful and faithful high priest. The emphasis of God's complete identification with Christians assures his (God's) care and support to people who are grappling with life challenges. That is, this understanding should provide African Christians the ability to cope in their life challenges without undermining God's ability to identify with them in their various contextual sufferings. In other words, as argued earlier, in moments of suffering, all Christians are exhorted to place their confidence in Jesus Christ as the sole merciful and faithful divine-human high priest, who is qualified to minster God to man. Thus, in concurrence with Bediako (2004) regarding the divinehuman nature of our New Adam:

His (Christ's) divine origin ensures that he is able to mediate between human community and the divine realm in a way no human priest can. As himself God-man, Jesus bridges the gulf between the Holy God and sinful humanity, achieving for humanity the harmonious fellowship with God that all human priestly mediations only approximate. (p. 29)

\section{Conclusion}

African Christian pastoral ministry is a challenging task. The limited contextually relevant models that respond to the existential and contextual life challenges of Africans compound the situation. In this essay we have established an Adamic Christological practical theological imagination for healing as a theory that is contextually relevant but maintains a clear Christian healing perspective without diminishing the actuality of Christ as God incarnate or encouraging syncretism in African Christianity. This theory was advanced after the biblical-theological foundational status of Adamic Christology was examined in Hebrews 2:5-18 and Luke 3:23-4:13. Adamic Christology was noted and applied as an 
alternative mediating category in enhancing African Christians' understanding of their full identification with Christ and consequently healing. The legitimacy of the Adamic Christological category was underscored mainly by examining the theological aspects of the Adam-Christ relationship, which are inherent in the fact that the entire human race is summed up in these two historical figures in two different ways. On the one hand, Adam is the head of fallen humanity; on the other hand, Christ is the head of redeemed humanity. In this continuity and discontinuity, Jesus Christ stands as the New Adam, who truly identifies with all humanity in his incarnation and reverses the Adamic sin together with its consequences for all people who believe (Rm. 1:16; Jn. 3:16) in his redemptive work.

In view of the Adamic Christological model and the consequent salvation it brings to all humanity, the implications of this model were brought to bear in African Christian healing ministry. We strongly argued that God in Christ has a complete identification with African people in their suffering as their New Adam. However, in order to oppose the misconception of God's discontinuous identification with African Christians owing to Christ's ascension, we argued for God's ongoing solidarity with believers in their suffering through the Holy Spirit. God's continuous solidarity with African Christians in their suffering through the Holy Spirit is an encouraging and comforting aspect for believers to cope in suffering. In saying this, we maintained that God not only has complete solidarity with African Christians in suffering but also the possibility of healing them. God heals Christians according to will. If God decides not to heal or save believers from their suffering moments, they (Christians) have to be cognisant that God is using their suffering to pursue their holiness or to nurture them into Christ-likeness. That is, Christians are encouraged to view their moments of suffering from God's perspective. Viewed this way, suffering is a way of developing Christian maturity in Christ. However, in the context of suffering, Christians' response should be shaped by the gospel promises (promissiotherapy), as well as taking our New Adam (Jesus Christ) as an ultimate model of how believers ought to respond to their suffering (identification).

The metaphor of the New Adam (Jesus Christ) as a suffering servant who truly identifies with Christians in their various contextual suffering was established as both healing and empowering for believers. In the incarnation, God in Christ truly identifies with humanity as the New Adam and he knows what it is to suffer as a human being; hence, there is no human experience that is foreign to him. He (Christ) knows what it is to be human in all aspects of life, but he did not commit sin. African Christians should have confidence that the God-man, Jesus Christ, has complete solidarity with them in their suffering, and he is able to bear with them in their suffering as the faithful and merciful high priest. Therefore, we recommend the above-mentioned theological approach as a model for African Christians' daily response to their various African contextual sufferings.

\section{Acknowledgements Competing interests}

The author declares that he has no financial or personal relationships that may have inappropriately influenced him in writing this article.

\section{Author's contributions}

V.M. conceptualised the article and its outline, including formulating the core research ideas and theme. C.M. mined the data and conducted preliminary data analysis. Both engaged in the writing, editing, critical reviewing and refining of the article for its completion.

\section{References}

Aguwa, J.C., 2007, 'Mission, colonialism, and the supplanting of African religious and medical practices', in M.K. Asante (ed.), African studies history, politics, economics, culture, pp. 127-145, Taylor \& Francis Group, Routledge, South Africa.

Aho Ekue, A.A., 2005, 'Troubled but not destroyed. The development of African theologies and the paradigm of theology of reconstruction', in K. Koschorke (ed.), African identities and World Christianity in the twentieth century, pp. 101-102, Harrassowitz Verlag, Wiesbaden.

Atkinson, D.J. \& Field, D.H., 1995, New dictionary of Christian ethics and pastoral theology, Inter-Vasity Press, Nottingham.

Banda, C., 2005, 'The sufficiency of Christ in Africa: A Christological challenge from African traditional religion', MA dissertation, University of South Africa, Pretoria.

Barth, K., 1956, Christ and Adam - Man and humanity in Romans 5, Oliver \& Boyd, Edinburgh.

Bediako, K., 1994, 'Understanding African theology in the 20th century', Themelios 20, 14-20.

Bediako, K., 2004, Jesus and the gospel in Africa: History and experience, Orbis Books, New York

Bock, D.L., 2012, A theology of Luke and Acts: God's promised programme, realised for all nations, Zondervan, Grand Rapids.

Bosch, D.J., 1993, Transforming mission: Paradigm shifts in theology of mission, Orbis Books, Maryknoll, NY.

Bowden, J., 2005, Christianity: The complete guide, Continuium, London.

Bromiley, G.W., 1982, The international standard Bible encyclopedia, vol. 2, William B. Eerdmans, Grand Rapids, MI.

Bujo, B., 1992, African theology in its social context, Orbis Books, Maryknoll, NY.

Cahalan, K.A. \& Mikoski, G.S. (eds.), 2014, Opening the field of practical theology: An introduction, Rowan and Littlefield, New York.

Calvin, J., 1948, Commentaries on the epistle of Paul the apostle to the Romans, transl. J. Owen, William B. Eerdmans, Grand Rapids, MI.

Cockerill, G.L., 2012, The epistle to the Hebrews, William B. Eerdmans, Grand Rapids, MI.

Coppedge, A., 1980, 'Holiness and discipleship', Wesleyan Theological Journal 15(2), 80-97.

Cortez, M., 2005, 'Creation and context: A theological framework for contextual theology', Westminster Theological Journal 67(2), 347-362.

Craddock, F.B., 1998, The letter to the Hebrews: The new interpreters Bible, Abingdon, Nashville, TN.

Culpepper, A.N., 1995, Introduction, commentary, and reflections: The new interpreters Bible, Abingdon, Nashville, TN.

De Gruchy, J., 1989, 'Salvation as healing and humanisation', in T.A. Hart \& D.P. Thimell (eds.), Christ in our place: The humanity of God in Christ for the reconciliation of the world, pp. 32-47, Paternoster, Exeter.

Dillon, R.J., 1998, 'The spirit as taskmaker and troublemaker in Romans 8', Catholic Biblical Quarterly 84(3), 234-252.

Dunn, J., 1989, Christology in the making: A New Testament inquiry into the origins of the incarnation, 2nd edn., William B. Eerdmans, Grand Rapids, MI.

Ellington, P., 1993, The epistle to the Hebrews: A commentary on the Greek text, William B. Eerdmans, Grand Rapids, MI.

Ellingworth, P., 1993, The Epistle to the Hebrews: A commentary on the Greek Text, William B. Eerdmans Publishing, Grand Rapids, MI.

Ezigbo, V.I., 2008, 'Contextualising the Christ-Event: A Christological study of the interpretations and appropriations of Jesus Christ in Nigerian Christianity', PhD thesis, University of Edinburgh, Edinburgh.

Farrow, D., 1999, Ascension and Ecclesia: On the significance of the doctrine of the Ascension for ecclesiology and Christian cosmology, William B. Eerdmans, Grand Rapids, MI. 
Fee, G.D., 1994, God's empowering presence: The holy spirit in the letters of Paul, Hendrickson Publishers, Peabody, MA.

Fischer, M., 2011, 'The spirit helps us in our weaknesses: Charismatisation of worldwide Christianity and the quest for an appropriate pneumatology with focus on the Lutheran church in Tanzania', Journal of Pentecostal theology 20(1), 95-121. http://dx.doi.org/10.1163/174552511X554573

Fowler, J.W., 1983, 'Practical theology and the shaping of Christian lives', in D.S Browning (ed.), Pastoral theology: The emerging field in theology, church and world, pp. 148-166, Harper and Row, San Francisco, CA.

George, T., 2011, Evangelicals and Nicene Faith: Recalling the apostolic witness, Bake Academic, Grand Rapids, MI.

Green, J.B., 1997, The gospel of Luke: The new international commentary on the New Testament, William B. Eerdmans, Grand Rapids, MI.

Gunton, C.E., 1992, Christ and creation, William B. Eerdmans, Grand Rapids, MI.

Hagner, D.A., 2005, 'The son of God as unique high priest: The Christology of the epistle to the Hebrews', in R.N. Longenecker (ed.), Contours of Christology in the New Testament, pp. 247-267, William B. Eerdmans, Grand Rapids, MI.

Horton, M., 2011, Christian faith: A systematic theology for pilgrims in the way Zondervan, Grand Rapids, MI.

Hultgren, A.J., 2011, Paul's letter to the Romans: A commentary, William B. Eerdmans, Grand Rapids, MI.

Hunter, R.J. 1995, 'The therapeutic tradition of pastoral care and counseling', in R.J. Hunter (ed.), Pastoral care and social conflict, pp. 17-31, Abingdon, Nashville, TN.

Igba, J., 2013, 'Ancestor Christology and Jesus' identity: A study based in the epistle to the Hebrews', MA dissertation, North West University, North West.

Jewett, R., 1981, Letter to pilgrims: A commentary on the epistle to the Hebrews, The Pilgrim Press, New York.

Kabasele, F., 1991, 'Christ as ancestor and elder brother', in R. Schreiter (ed.), Faces of Jesus in Africa, pp. 103-115, Orbis Books, Maryknoll, NY.

Kruse, C.G., 2012, Paul's letter to the Romans, William B. Eerdmans, Grand Rapids, MI.

Kwesi, D., 1984, Theology in Africa, Orbis Books, Maryknoll, NY.

Livingstone, D.N., 2008, Adam's ancestors: race, religion, and the politics of human origins, Johns Hopkins University Press, Baltimore, MD.

Louw, D.J., 1998, A pastoral hermeneutics of care and encounter, Lux Verbi, Cape Town.

Louw, D.J., 2003, 'The healing dynamics of space: Relational and systemic therapy in pastoral care to people suffering from poverty', in P.D. Couture \& B. Millerpastoral care to people suffering from poverty', in P.D. Couture \& B. Miller-
McLemore (eds.), Poverty, suffering and HIV/AIDS: International practical theological perspectives, pp. 209-218, Cardiff Academic Press, Fairwater.

Louw, D.J., 2008, Cura Vitae: Illness and the healing of life in pastoral care and counselling, Lux Verbi, Cape Town.

Louw, D.J., 2014, Wholeness in hope care on nurturing the beauty of the human soul in spiritual healing, LIT, Wien.

Magezi, V., 2007, 'Pastoral counseling: Towards a diagnostic and interpretational approach in Africa', Die Skriflig 41(4), 655-672. http://dx.doi.org/10.4102/ids. v41i4.325

Marshall, H., 1978, The Gospel of Luke: A commentary in the Greek text, William B. Eerdmans, Grand Rapids, MI.

Marshall, H., 2005, 'The Christology of Luke's gospel and Acts', in R.N. Longenecker (ed.), Contours of Christology in the New Testament, pp. 122-147, William B. Eerdmans, Grand Rapids, MI.
Mbiti, J., 1986, Bible and theology in African Christianity, Oxford University Press, Nairobi.

Mbiti, J., 1989, African religions and philosophy, Heinemann, London.

Milingo, E., 1984, The world in between: Christian healing and the struggle for spiritua survival, Orbis Books, Maryknoll, NY.

Mkole, J.C.L., 2000, 'Mark 14:62: Substantial compendium of New Testament Christology', HTS 56(4), 1119-1145.

Moo, D.J., 1996, The epistle to the Romans, William B. Eerdmans, Grand Rapids, MI.

Need, S.W., 2008, Truly divine and truly human: The story of Christ and the seven ecumenical councils, Hendrickson Publishers, Peabody.

Nyamiti, C., 2006, Studies in African Christian Theology, vol. 2, Jesus Christ, the Ancestor of Humankind: An essay on African Christianity, CUEA Publications, Nairobi.

O'Brien, P.T., 2010, The letter to the Hebrews, William B. Eerdmans, Grand Rapids, MI.

Olagunju, J., 2013, 'Sin, sickness, and salvation: A holistic approach to healing', Ogbomoso Journal of Theology 18(2), 112-121.

Orboji, F., 2008, 'African theology, Roman Catholic', in W.A. Dyrness \& V.M. Kärkkäinen (eds.), Global dictionary of theology: A resource for the world-wide church, pp. 15-20, IVP Academic, Downers Grove, IL.

Owen, J., 1965, 'The holy spirit', in W.H. Goold (ed.), The works of John Owen, vol 3 , Banner of Truth, Edinburgh.

Palmer, T., 2008, 'Jesus Christ: Our ancestor?', Africa Journal of Evangelical Theology 27(1), 65-76.

Pobee, J., 1979, Towards an African theology, Abingdon Press, Nashville, TN.

Reed, R. \& Mtukwa, G., 2010, 'Christ our ancestor: African Christology and the danger of contextualisation', Wesleyan Theological Journal 45(1), 144-163.

Ryken, P.G., 2009, Reformed expository commentary, P \& R Publishing, Phillipsburg, NJ.

Salala, C., 1998, 'The world of the Spirits: Basukuma tradi onal religion and Biblical Chris anity', in S. Ngewa, M. Shaw \& T. Tienou (eds.), Issues in African theology, pp. 133-138, East African Educa on Publishers, Nairobi.

Schreiner, T.R., 1998, Romans, Baker Books, Grand Rapids, MI.

Seccombe, D., 2002, The king of God's kingdom: A solution to the puzzle of Jesus, Paternoster, Crownhill.

Setiloane, G.M., 1976, The image of God among the Sotho-Tswana, Balkema, Rotterdam.

Stein, R.H., 1973, The new American commentary, An exegetical and theological exposition of holy scripture: Luke, Broadman Press, Nashville, TN.

Taylor, J.V., 1963, The primal vision: Christian presence amid African religion, SCM Press, London

Torrance, T.F., 1992, The mediation of Christ, Williams B. Eerdmans, Grand Rapids, MI.

Torrance, T.F., 2008, Incarnation: The person and life of Christ, IVP Academic, Downers Grove, IL.

Torrance, T.F., 2009, Atonement: The person and work of Christ, IVP Academic, Downers Grove, IL.

Wacheche, P., 2012, 'Modern trends in Christianity', MA dissertation, Nairobi University, Nairobi.

Wright, N.T., 2002, The letter to the Romans: The new interpreter's Bible, Abingdon Press, Nashville, TN. 